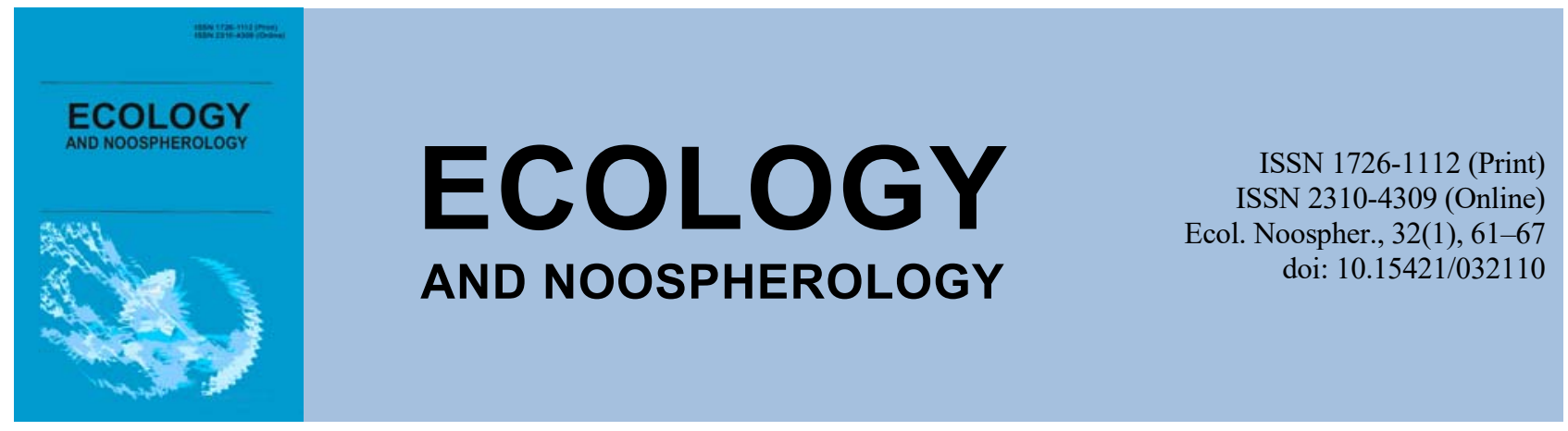

\title{
To the reproduction biology of the Wryneck (Jynx torquilla Linnaeus, 1758) in artificial nests in Northeastern Ukraine
}

\author{
O. O. Yarys
}

\section{H. S. Skovoroda's Kharkiv National Pedagogical University, Kharkiv, Ukraine}

Article info

Received 19.05.2021

Received in revised form 25.05.2021

Accepted 14.06.2021

H. S. Skovoroda's Kharkiv National Pedagogical

University, Alchevsky st., 29, Kharkiv, 61002, Ukraine.

Tel.: + 38-066-086-36-42

E-mail:

lena.chebitko.95@ukr.net
Yarys, O. O. (2021). To the reproduction biology of the Wryneck (Jynx torquilla Linnaeus, 1758) in artificial nests in Northeastern Ukraine. Ecology and Noospherology, 32(1), 61-67. doi:10.15421/032110

In many countries, the Jynx torquilla population has declined significantly. In Ukraine, the species is considered widespread, but remains poorly studied. Activities to attract birds to parks using artificial nests were carried out during 2004-2021 in Northeastern Ukraine. The first time the $J$. torquilla was populated in artificial nests dates back to 2009. During 2019-2021 4 cases of $J$. torquilla nesting in artificial nests were recorded. Among the studied territories, the population of $J$. torquilla in artificial nests was found in the territory of the regional landscape park (RLP) «Feldman Ecopark», NPP «Gomilshansky forests» near the village. Gaidary in Kharkov and the tract «Vakalovschina» near the village Vakalovschina in Sumy regions. In the Northeastern of Ukraine, the number of $J$. torquilla reaches $14,3 \pm 0,32$ pairs $/ \mathrm{km}^{2}$ in the oak forests of the NPP «Gomilshansky forests» near the village Gaidary, $7,2 \pm 0,14$ pairs $/ \mathrm{km}^{2}$ in the pine forests of the park near the village Zadonetske, $16,2 \pm 0,14$ pairs $/ \mathrm{km}^{2}$ in the «Vakalovschina» tract, $11,1 \pm 0,24$ pairs $/ \mathrm{km}^{2}$ in RLP «Feldman Ecopark». J. torquilla, as a typical hollow-hole, is able to inhabit artificial nests. On average, during 2004-2021, the arrival of the first individuals in the spring was recorded: 21.04 at an average daily temperature of $18^{\circ} \mathrm{C}$ in the oak grove of the NPP "Gomilshansky forests», 23.04 at a temperature of $17^{\circ} \mathrm{C}$ in the tract «Vakalovschina», on the territory RLP «Feldman Ecopark» - 02.05 at a temperature of $17^{\circ} \mathrm{C}, 2020$ is 05.05 at a temperature of $20^{\circ} \mathrm{C}$. It has been proven that 12 days pass from the moment of arrival of birds to the laying of the first egg. The first eggs of birds in the conditions of Northeastern Ukraine, on average, for all years of research, were registered 02.05 in the oak grove of the NPP «Gomilshansky forestsn», 04.05 in the tract «Vakalovschina». On the territory of RLP «Feldman Ecopark» in 2019, the first egg was laid at 14.05 on the material of the nest of the collared flycatcher Ficedula albicollis (Temm., 1815); in 2020 - 19.05. Average clutch size 8,3 $\pm 0,5$ (from 7 to 9). Egg sizes: length $-20,2 \pm 0,2 \mathrm{~mm}$, width $-15,1 \pm 0,1 \mathrm{~mm}$, volume $-1.4 \pm 0.1 \mathrm{~mm}^{3}$, roundness index $-74.7 \pm 0.3 \%$. On average, incubation lasts $13 \pm 0,2$ days. On the territory of the NPP «Gomilshansky forests» near the village. Gaidary, chicks hatched at 14.05; in the tract «Vakalovschina» on 16.05, on the territory of the RLP «Feldman Ecopark» in 2019 the chicks hatched on 26.05 , in $2020-01.06$. The hatching success was found to be $96,9 \%(\mathrm{n}=30)$, where the breeding success is $91,0 \%$.

Keywords: artificial nests; Jynx torquilla L.; hollow-nesting birds; Northeastern Ukraine

\section{До біології розмноження крутиголовки (Jynx torquilla Linnaeus, 1758) у штучних гніздівлях в умовах північного сходу України}

\author{
О. О. Ярис
}

\author{
Харківський національний педагогічний університет імені Г. С. Сковороди, Харків, Україна
}

У багатьох країнах популяція крутиголовки (Jynx torquilla Linnaeus, 1758) значно скоротилася. В Україні вид вважається широко розповсюдженим, проте залишається досі слабо вивченим. Заходи щодо приваблювання птахів у парки за допомогою штучних гніздівель проводили протягом 2004-2021 pp. в умовах північного сходу України. Серед 
досліджуваних територій заселеність Jynx torquilla у штучних гніздівлях виявлено на території регіонального ландшафтного парку (РЛП) «Фельдман Екопарк», НПП «Гомільшанські ліси» поблизу с. Гайдари у Харківській та урочища «Вакалівщина» поблизу с. Вакалівщина у Сумській областях. В умовах північного сходу України чисельність Jynx torquilla досягає

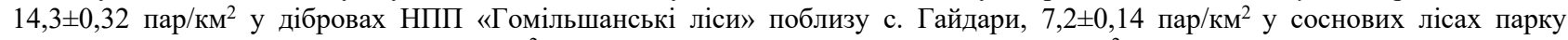

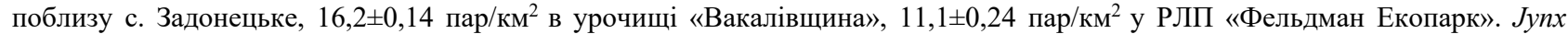
torquilla, як типовий дуплогнізник, здатен заселяти штучні гніздівлі. В середньому протягом 2004-2021 pр. приліт навесні перших особин реєстрували: 21.04 при середньодобовій температурі $+18{ }^{\circ} \mathrm{C}$ у діброві НПП «Гомільшанські ліси», 23.04 при температурі $+17^{\circ} \mathrm{C}$ в урочищі «Вакалівщина», на території РЛП «Фельдман Екопарк» - у 2019 році 02.05 при температурі $+17{ }^{\circ} \mathrm{C}$, у 2020 році 05.05 при температурі $+20^{\circ} \mathrm{C}$. Досліджено, що від дати прильоту птахів до відкладання першого яйця проходить 12 діб. Перші яйця птахів в умовах північного сходу України в середньому за всі роки досліджень зареєстровано 02.05 у діброві НПП «Гомільшанські ліси», 04.05 в урочищі «Вакалівщина». На території РЛП «Фельдман Екопарк» у 2019 році перше яйце відкладене 14.05 на матеріалі гнізда Ficedula albicollis (Temm., 1815); у 2020 році - 19.05. Середня

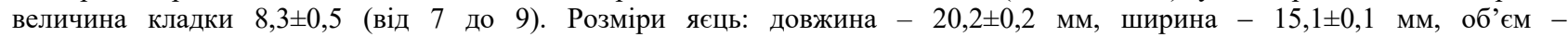

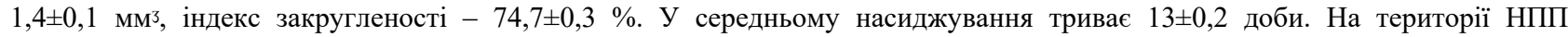
«Гомільшанські ліси» поблизу с. Гайдари за роки досліджень пташенята вилупилися 14.05; в урочищі «Вакалівщина» 16.05 , на території РЛП «Фельдман Екопарк» у 2019 році пташенята вилупилися 26.05, у 2020 - 01.06. 3'ясовано, що успішність вилуплення становить $96,9 \%(\mathrm{n}=30)$, де успіх розмноження становить $91,0 \%$.

Ключові слова: штучні гніздівлі; Jynx torquilla L.; дуплогнізні птахи; північний схід України

\section{Вступ}

В останні роки популяція J. torquilla (L., 1758) у Центральній Свропі різко скоротилася (Becker, Tolkmitt, 2011), у багатьох країнах даний вид $є$ рідкісним (Резниченко, 2013; Brünner, Rödl, 2018; Taylor et al., 2020; Dolenec, 2020). Основними причинами зменшення чисельності птахів є знищення середовища їх існування (Assandri et al., 2018), надмірне удобрювання та використання пестицидів (Weisshaupt et al., 2011), зменшення основного джерела корму (наземні мурахи) i відповідно відсутність місць для гніздування (Dolenec, 2020). Між іншим, під час міграцій ці птахи розбиваються об дроти ліній електропередач (Shumaev, 2021). Тому забезпечення птахів належними штучними гніздівлями $\epsilon$ необхідним та важливим заходом у підтриманні їх популяції. Такої думки дотримуються і швейцарські орнітологи, які акцентують увагу у своїх дослідженнях на дизайні штучних гніздівель для J. torquilla та їх розміщенні у правильно підібраних територіях. Так, у Атласі гніздових птахів Німеччини зазначено, що $J$. torquilla зустрічається в тропічному, помірному і північному кліматі північнозахідної Африки. Поширюється від континентальної Європи до Японії. Основні європейські угрупування знаходяться в Східній Свропі і в Середземноморському регіоні (Gedeon et al., 2014). Населяє відкриті та напіввідкриті, кліматично сприятливі ландшафти (Андрющенко и др., 2015). У Баден-Вюртемберзі цей вид обирає місця для гніздування: фруктові сади, галявини, відкриті ліси (листяні, хвойні), парки (Del Val et al., 2018); у Швейцарії віддає перевагу виноградникам (Zingg et al., 2010); у Словакії - кладовищам (Csanady, Mošansky, 2017). У Казахстані J. torquilla обирає долини річок Урал і Ілек, в Кокчетовському нагір'ї, по Іртишу, на Південно-Західному, Південному Алтаї та Джунгарському Алатау верхів'я річки Тентек (Gavrilov et al., 2017).

В Україні $J$. torquilla гніздиться по всій території, крім високогір'я; мігрує скрізь (Shevtsov, 2008; Biletska et al., 2009; Beskaravajnyj et al., 2012; Havryliuk et al., 2014; Rudenko et al., 2016). Є звичайним гніздовим видом різних типів лісів (Chaplygina et al., 2016). Трапляється майже в усіх типах лісосмуг (Petrovych, 2014; Tarusova, 2019; Pisotska \& Yarys 2021); зареєстрована в лісосмугах 3 відповідним типом зволоження у степовій зоні біосферного заповідника «Асканія-Нова» імені Ф. Е. Фальц-Фейна НААН України (Lystopadskyi, 2014).

Незважаючи на широке розповсюдження в Україні (Fesenko \& Bokotei, 2002), залишається досі слабо вивченим видом у багатьох частинах свого ареалу. Мета досліджень - виявлення особливостей гніздування $J$. torquilla у штучних гніздівлях в умовах північного сходу України.

\section{Об'єкти та методи досліджень}

Заходи щодо приваблювання птахів за допомогою штучних гніздівель (ШГ) проводили протягом 2004-2021 pp. в умовах північного сходу України (Chaplyhina, 2018). Серед досліджуваних територій заселеність J. torquilla у штучних гніздівлях (ШГ) виявлено на території регіонального ландшафтного парку (РЛП) «Фельдман Екопарк», НПП «Гомільшанські ліси» поблизу с. Гайдари у Харківській та урочища «Вакалівщина» поблизу с. Вакалівщина у Сумській областях. Згідно 3 фізикогеографічним районуванням територія РЛП «Фельдман Екопарк» відноситься до Харківської схилово-височинної області Середньоруської лісостепової провінції Лісостепової зони, а тому відрізняється значним флористичним багатством (Chaplyhina, 2018). У першому ярусі дуб звичайний (Quercus robur L.) з домішкою липи серцелистої (Tilia cordata Mill.), поодиноко трапляється клен гостролистий (Acer platanoides L.), другий ярус зазвичай не виражений. У підрості трапляється клен польовий (A. campestre L.). Підлісок середньої щільності складається із ліщини звичайної (Corylus avellana L.), клена татарського (A. tataricum L.), бруслини європейської (Euonymus europaeus L.), дерену-свидини (Cornus sanguinea L.). У трав'янистому ярусі переважають осока волосиста (C. Pilosa Scop.), анемона жовтецева (Anemone ranunculoides L.), купина багатоквіткова (Polygonatum multiflorum (L.) All.), яглиця звичайна (Aegopodium podagraria L.), копитняк європейський (Asarum europaeum L.), проліска сибірська (Scilla siberica Andrews).

НПП «Гомільшанські ліси» розташований на межі двох природних зон, що пояснює особливості складу різних типів рослинності. На території парку переважає лісовий тип рослинності. На вершинах схилів - суха кленоволипова діброва. у деревостані території НПП «Гомільшанські ліси» поблизу с. Задонецьке домінує сосна звичайна (Pinus sylvestris L.), супутніми породами є ясен звичайний (Fraxinus excelsior L.), A. campestre L., T. cordata Mill. У чагарниковому ярусі зростають A. tataricum L., терен колючий (Prunus spinosa L.), глід кривочашечковий (Crataegus curvisepala Lindm.), в'яз корковий (Ulmus suberosa Moench), жостір проносний (Rhamnus cathartica L.), малина звичайна (Rubus idaeus L.). Серед трав'янистих рослин лісу $є$ : орляк звичайний (Pteridium aquilinum (L.) Kuhn), купина запашна (Polygonatum odoratum (Mill.) Druce), просянка розлога (Milium effusum L.), костриця Беккера (Festuca beckeri Hack.) Trautv.), волошка лучна (Centaurea jacea L.), свербіжниця польова (Knautia arvensis (L.) Coult.), звіробій звичайний (Hypericum perforatum L.), віхалка гілляста (Anthericum ramosum L.), молочай південноєвропейський (Euphorbia nicaeensis All.), конвалія звичайна (Convallaria 
majalis L.), сон чорніючий (Pulsatilla pratensis (L.) Mill.), фіалка запашна (Viola odorata L.). Діброва парку поблизу c. Гайдари має складну багатоярусну структуру. Деревний ярус складається 3 дуба черешчатого (Quercus robur L.), клена гостролистого (Acer platanoides L.), береста (Ulmus minor L.), липи серцелистої (Tilia cordata Mill.), груші звичайної (Pyrus communis L.), ясена звичайного (Fraxinus excelsior L.), , яблуні лісової (Malus sylvestris Mill.). В чагарниковому ярусі звичайно зустрічаються ліщина (Corylus avellana L.), бруслина європейська (Euonymus europaea L.) і бруслина бородавчаста (Euonymus verrucosa Scop.). У трав'янистому ярусі переважають: осока волосиста (Carex pilosa L), копитняк європейський (Asarum europaeum L.), папороть (Dryopteris filix-mas L.).

Урочище «Вакалівщина» розташоване поблизу c. Вакалівщина на окраїні великого масиву нагірних i вододільних широколистяних лісів. У лісоценотичній структурі цього урочища переважають кленово-липоводубові та ясенево-дубові ліси 3 деревостаном віком 90120 років (Knysh, 1998). В підліску можна зустріти садовий жасмин вінцевий (Philadelphus coronarius L.), C. avellana L., черемху звичайну (P.padus L.). У трав'янистому ярусі лісу $\epsilon$ празелень звичайна (Lapsana communis L.), P. multiflorum (L.) All., V. odorata L., бугила лісова (Anthriscus sylvestris (L.) Hoffm.); саду біостаціонару СумДПУ ім. А. С. Макаренка $H$. perforatum L., золотушник канадський (Solidago canadensis L.), незабудка Myosotis sp., жовтець їдкий (Ranunculus acris L.), скереда сибірська (Crepis sibirica L.), люцерна серпувата (Medicago falcata L.), тонконіг (Poa sp.), королиця звичайна (Leucanthemum vulgare Lam.), злинка однорічна (Erigeron annuиs (L.) Desf.), молочай гострий (E. esula L.), материнка звичайна (Origanum vulgare L.), парило звичайне (Agrimonia eupatoria L.), конюшина лучна (Trifolium pratense L.), салат компасний (Lactuca serriola L.), чина лучна (Lathyrus pratensis L.), подорожник (Plantago sp.).

В умовах північного сходу України (на досліджуваних територіях) розвішано понад 500 ШГ на висоті до 3 м від землі та на відстані від 5 до 50 м одна від одної. Виготовлені із дощатого матеріалу, стандартних розмірів для дрібних дуплогнізних птахів 3 діаметром льотка $3,0-5,0$ см; відкривається передня або верхня кришка.

Заселеність ШГ перевіряли в період гніздування протягом березня - червня. Перший випадок заселення J. torquilla у ШГ відноситься до 2009 року. Протягом 2019-2021 pр. зафіксовано 4 випадки гніздування $J$. torquilla у ШГ. Проаналізовано і визначено середні оологічні показники яєць (Myand, 1988; Hoyt, 1979). Установлено середні розміри кладок. За оцінку відтворення популяцій птахів використано показник успішності розмноження. Визначення віку пташенят J. torquilla досліджували візуально за станом, розмірами і розвитком їхнього оперення. Обрахунок чисельності птахів проводили маршрутним методом для лісових ландшафтів без обмеження ширини облікової смуги 3 подальшим роздільним перерахунком щільності населення $($ пар/км²) (Chaplyhina, 2018). Рослинність в умовах північного сходу України досліджували за визначником (Prokudin et al., 1987). Статистичну обробку отриманих даних здійснювали в пакеті MS Excel та Past 4.03.

\section{Результати та їх обговорення}

В умовах північного сходу України чисельність $J$. torquilla досягає $14,3 \pm 0,32$ пар/км² у дібровах НПП «Гомільшанські ліси» поблизу с. Гайдари, у соснових лісах парку поблизу с. Задонецьке 7,2 $\pm 0,14$ пар/км², в урочищі «Вакалівщина» 16,2 $\pm 0,14$ пар/км² (Chaplyhina, 2018), у РЛП «Фельдман Екопарк» 11,1 $\pm 0,24$ пар/км². За даними M. Матвієнко (2009), найбільш багаточисленні в байрачних та заплавних лісах, які мають достатню кількість дупел. І. Мерзлікін (2021) описує гніздування J. torquilla у людських помешканнях (на горищі 4-поверхового будинку), у ніші воріт господарської будівлі, у щілині кам'яної стіни, у шалівці обшивки будинку, у тріщинах між дерев'яними накатами траншеї та в щілині на вершині бетонного стовпа колишньої лінії електропередач, у металічній трубі.

На території України $J$. torquilla зазвичай з'являється навесні в першій половині квітня. Найранніший приліт птахів в околицях м. Києва -4 квітня 1926 р., найпізніший 26 квітня 1958 р., у м. Черкаси - 26 березня - 18 квітня, у м. Львові - 11-29 квітня, в Криму приліт триває весь квітень та протягом першої декади травня (Beskaravajnyj, 2012). У районі Кременчуцького водосховища протягом 2003-2012 рр. приліт J. torquilla зареєстровано: 12.04.09 (Іркліїв) - 06.04.08 (Ірдинь) - 16.04.06 (Ч. Слобода) 10.04.05 (Мельники) - 18.04.04 (Станіславчик) (Havryliuk et al., 2014). В Олександрійському районі Кіровоградської області приліт зафіксований: 30.04 .97 - 14.04 .99 03.04.2000 - 13.04.01 - 19.04.02 - 15.04.03 - 17.04.04 13.04.05 - 16.04.06 (Shevtsov, 2008). Протягом щорічних спостережень на біологічному стаціонарі СумДПУ iм. А. С. Макаренка, розташованому поруч із c. Вакалівщина, визначено приліт J. torquilla між 11.04 (1972 i 1977 pp.) i 26.04 (1997 p.) (Knysh, 1998).

Перші весняні мігранти у Харківській області зареєстровані в першій декаді квітня: найранніше 8 квітня 1990 р., найпізніше - 2 травня 1987 p. (Nadtochij, Chaplygina, 2010), що збігається 3 даними М. Сомова (1897). В умовах північного сходу України протягом 20042021 pp. перших особин реєстрували: 21.04 при середньодобовій температурі $+18{ }^{\circ} \mathrm{C}$ у діброві НПП «Гомільшанські ліси», 23.04 при температурі $+17{ }^{\circ} \mathrm{C}$ в урочищі «Вакалівщина», на території РЛП «Фельдман Екопарк» -02.05 при температурі $+17^{\circ} \mathrm{C}$, у 2020 році 05.05 при температурі $+20^{\circ} \mathrm{C}$ (рис. 1 ).

Результати дослідження показали, що J. torquilla почала гніздування у ШГ в умовах північного сходу України $27.04 \pm 3,1$ доби, у середньому при температурі $+18,0 \pm 0,7^{\circ} \mathrm{C}$. За багаторічними спостереженнями, цей вид зрідка будує «справжнє гніздо». У праці В. Бутьева та ін. (Butev et al., 2005) є свідчення про те, що як гнізда $J$. torquilla використовують підстилку сухої трави та корінці трав'янистих рослин. В дуплах підстилкою слугують тріски, які птахи добувають, дзьобаючи стінки дупел, особливо їх верхню частину. Крім того, дуже часто у гніздах можна знайти: камінці, скло, метал, фарфор, шпаклівку, суху фарбу, пластик, частинки кісток.

Від дати прильоту птахів до відкладання першого яйця минає 12 діб. Загальну розтягнутість періоду початку кладок, імовірно, можна пов'язати 3 нестабільністю весняної погоди. В умовах північного сходу України протягом 2004-2021 pp. перше яйце $J$. torquilla у ШГ зареєстровано 02.05 у діброві НПП «Гомільшанські ліси», 04.05 в урочищі «Вакалівщина». На території РЛП «Фельдман Екопарк» у 2019 році перше яйце було відкладене 14.05 на матеріалі гнізда мухоловки білошийої (Ficedula albicollis Temm., 1815) цього ж року; у 2020 році - 19.05. У середньому початок кладки яєць на досліджуваних територіях припадає на $09.05 \pm 4,0$ доби.

Під час досліджень нами виявлено 4 гнізда J. torquilla у ШГ, виміряно 33 яйця. Форма яєць правильно яйцевидна, еліпсоїдна, видовжена. Яйця чисто-білі глянцеві, ледь жовтуваті від жовтка, який просвічується через шкаралупу (рис. 2).

Величина кладки у $J$. torquilla змінюється від 7 до 9, середній показник складає $8,3 \pm 0,5$ яєць $(\mathrm{n}=4)$, переважають 9-яйцеві кладки.

У середньому довжина яєць становить $20,2 \pm 0,2$ мм,

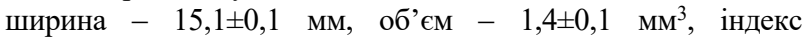

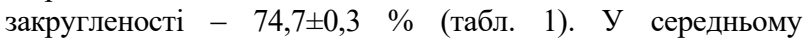
насиджування триває $13 \pm 0,2$ доби. Успішність вилуплення становить $96,9 \%(n=30)$, розмноження $-91,0 \%$. 


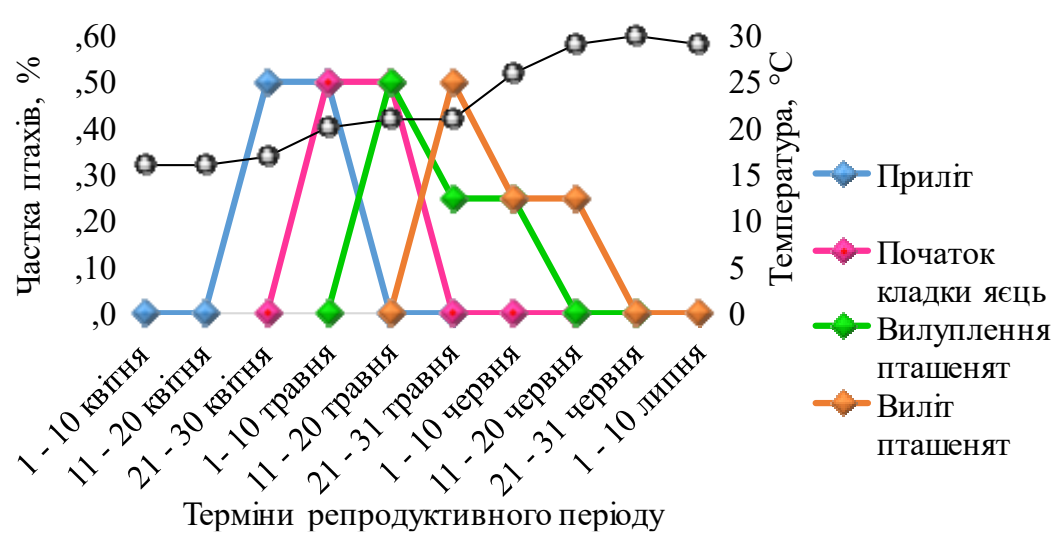

Рис. 1. Залежність термінів репродуктивного періоду від температури повітря в умовах північного сходу України протягом 2019-2021 рр.

Таблиця 1

Середні оологічні показники яєць $J$. torquilla у штучних гніздівлях на різних територіях

\begin{tabular}{|c|c|c|c|c|c|c|c|c|c|c|}
\hline 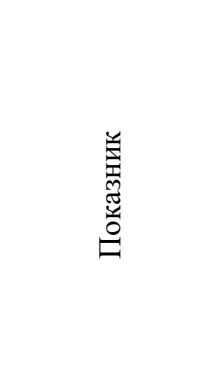 & 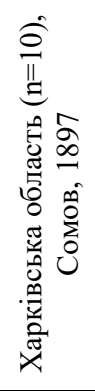 & 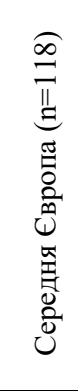 & 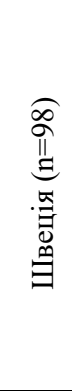 & 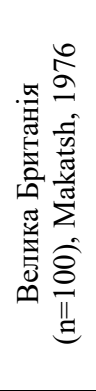 & 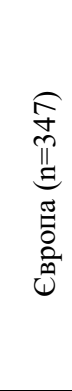 & 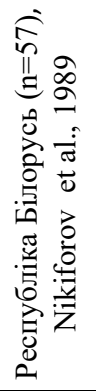 & 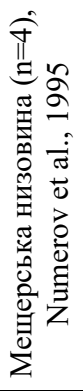 & 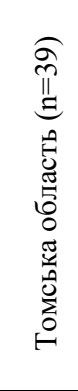 & 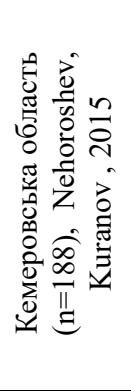 & 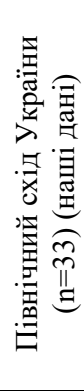 \\
\hline $\begin{array}{l}\text { Довжина (L) } \\
\text { яєць, мм } \\
\end{array}$ & 20,4 & 20,4 & 21,3 & 20,8 & 20,7 & 20,3 & 12,2 & 20,3 & 20,2 & 20,2 \\
\hline $\begin{array}{l}\text { Діаметр } \\
\text { (ширина) (D) } \\
\text { яєць, мм }\end{array}$ & 15,4 & 15,5 & 15,9 & 15,4 & 15,6 & 15,2 & 10,1 & 15,3 & 15,6 & 15,1 \\
\hline $\begin{array}{l}\text { Індекс } \\
\text { закругле- } \\
\text { ності (Sph) } \\
\text { яйця, \% }\end{array}$ & 75,1 & 76 & 74,6 & 74 & 78,5 & 76 & 84,5 & 75,2 & 77,3 & 74,7 \\
\hline $\begin{array}{l}\text { Індекс об'єму } \\
\text { (V) яйця, мм }{ }^{3}\end{array}$ & 2,4 & 2,5 & 2,7 & 2,5 & 2,4 & 2,5 & 0,7 & 2,4 & 2,5 & 2,3 \\
\hline
\end{tabular}

За роки багаторічних досліджень у Харківській області та інших країнах встановлено, що довжина (L) яєць суттєво відрізняється від показників, які реєстрував A. Нумеров (Numerov et al., 1995) у Мещерській низовині $12,2 \pm 0,2$ мм, відповідно показники діаметру (D) яєць менші - 10,1 \pm 0 мм, у порівнянні з іншими територіями. Можливо, такі суттєві показники яєць пов'язані 3 порушеннями репродуктивної системи молодої самки. Об'єм яєць (V) (Kruskal-Wallis $\chi^{2}=8,236 ; \mathrm{df}=3 ; \mathrm{p}=0,4373$ ) та показник індексу закругленості (Sph) (Kruskal-Wallis $\chi^{2}=8,945 ; \mathrm{df}=3 ; \mathrm{p}=0,4373$ ) значущих відмінностей між досліджуваними територіями не має.

Насиджування яєць $J$. torquilla у середньому триває $13 \pm 0,2$ доби. На території НПП «Гомільшанські ліси» поблизу с. Гайдари протягом 2004-2021 рр. пташенята вилупилися 14.05 ; в урочищі «Вакалівщина» 16.05 , на території РЛП «Фельдман Екопарк» у 2019 році пташенята вилупились 26.05 , у 2020 - 01.06. За період досліджень вилупилось 32 пташеняти. Як відомо, вид $J$. torquilla не має вираженого статевого диморфізму (Butev et al., 2005) Тому в ході спостережень самку на території РЛП «Фельдман Екопарк» визначали за кільцем, меншими розмірами та більш тьмяним забарвленням, у порівнянні із самцем (рис. 3).

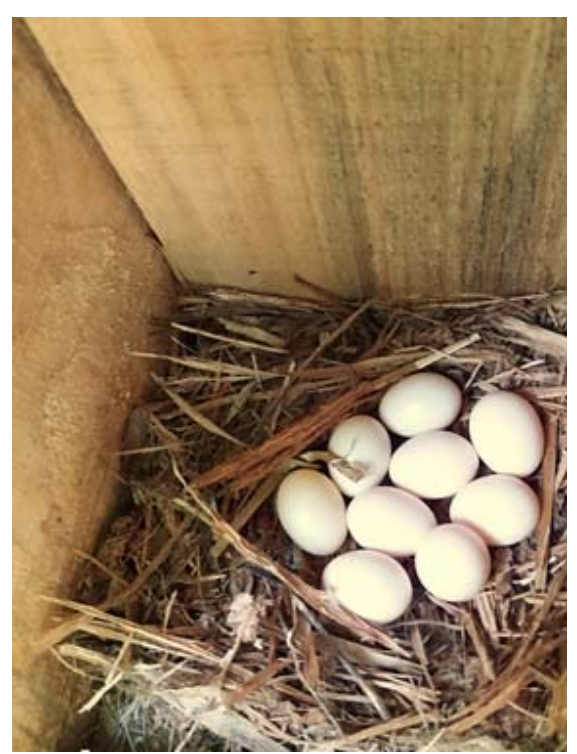

Рис. 2. Кладка яєць Jynx torquilla у штучній гніздівлі на території РЛП «Фельдман Екопарк» 


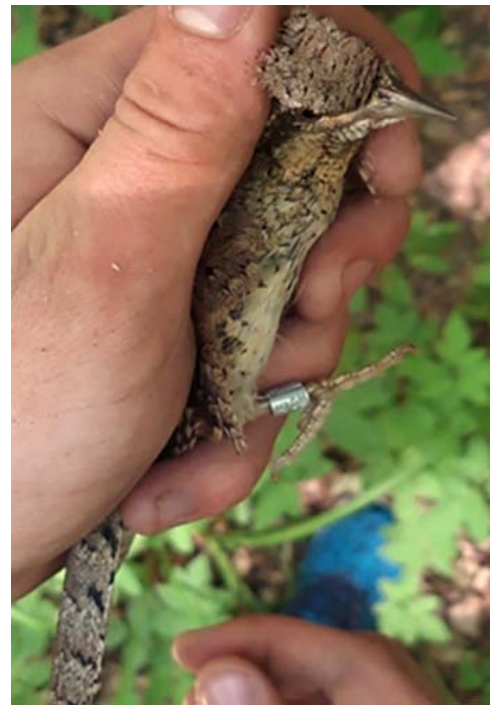

Рис. 3. Кільцювання Jynx torquilla на території регіонального ландшафтного парку «Фельдман Екопарк» у 2019 році

Виходячи 3 цього, установлено, що у вигодовуванні пташенят $J$. torquilla брали участь обидва дорослих птахи; послід частіше виносить самець, ніж самка. У гнізді після вильоту пташенят (27.05-15.06) знайдених яєць та шкаралуп виявлено не було. Успішність розмноження $J$. torquilla в умовах північного сходу України у середньому становила 91,0 \% (n=30) (табл. 2).

\section{Таблиця 2}

Успішність розмноження Jynx torquilla залежно від розміру кладки в умовах північного сходу України протягом 2019-2021 pp.

\begin{tabular}{|c|c|c|c|c|c|c|}
\hline \multirow[b]{2}{*}{$\begin{array}{l}\text { Роз- } \\
\text { мір } \\
\text { клад- } \\
\text { ки }\end{array}$} & \multicolumn{2}{|c|}{ Кількість } & \multicolumn{2}{|c|}{$\begin{array}{c}\text { Вилупилося } \\
\text { пташенят }\end{array}$} & \multicolumn{2}{|c|}{$\begin{array}{c}\text { Вилетіло } \\
\text { пташенят }\end{array}$} \\
\hline & 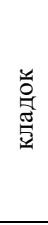 & $\begin{array}{c}\text { яєць } \\
\text { у } \\
\text { гніз- } \\
\text { дах }\end{array}$ & $\begin{array}{c}\text { частка від } \\
\text { вихідного } \\
\text { числа } \\
\text { яєць, \% }\end{array}$ & $\begin{array}{c}\text { у } \\
\text { серед- } \\
\text { ньому } \\
\text { на } \\
1 \text { пару }\end{array}$ & $\begin{array}{c}\text { частка } \\
\text { від } \\
\text { вихід- } \\
\text { ного } \\
\text { числа } \\
\text { яєць, } \\
\% \\
\end{array}$ & $\begin{array}{c}\text { у } \\
\text { серед- } \\
\text { ньому } \\
\text { на } \\
1 \text { пару }\end{array}$ \\
\hline 7 & 1 & 7 & 100 & 7,0 & 100 & 7.0 \\
\hline 8 & 1 & 8 & 100 & 8,0 & 75 & 6.0 \\
\hline 9 & 2 & 18 & 94,4 & $8,5 \pm 0.5$ & 100 & 9,0 \\
\hline
\end{tabular}

Найбільша $100 \%$-на $(8,0$ злетків на 1 пару; $\mathrm{n}=24)$ успішність розмноження Jynx torquilla на території РЛП «Фельдман Екопарк».

\section{Висновки}

1. В умовах північного сходу України Jynx torquilla $€$ типовим дуплогнізним птахом кленово-липово-дубових, ясено-дубових, соснових лісів. Найбільша чисельність даного виду зареєстрована в урочищі «Вакалівщина» $16,2 \pm 0,14$ пар/км².

2. Протягом 2004-2021 pp. перших особин навесні реєстрували: 21.04 при середньодобовій температурі $+18{ }^{\circ} \mathrm{C}$ у діброві НПП «Гомільшанські ліси», 23.04 при температурі $+17^{\circ} \mathrm{C}$ в урочищі «Вакалівщина», на території РЛП «Фельдман Екопарк» - 02.05 при температурі $+17^{\circ} \mathrm{C}$, у 2020 році 05.05 при температурі $+20^{\circ} \mathrm{C}$.

3. Від дати прильоту птахів до відкладання першого яйця проходить 12 діб. Перші яйця птахів в умовах північного сходу України протягом 2004-2021 pp. зареєстровано 02.05 у діброві НПП «Гомільшанські ліси»,
04.05 в урочищі «Вакалівщина». На території РЛП «Фельдман Екопарк» у 2019 році перше яйце відкладене 14.05 на матеріалі гнізда Ficedula albicollis цього ж року; у 2020 році - 19.05 .

4. Середня величина кладки $8,3 \pm 0,5$ (від 7 до 9). Розміри яєць: довжина 20,2 $\pm 0,2$ мм, ширина $-15,1 \pm 0,1$ мм,

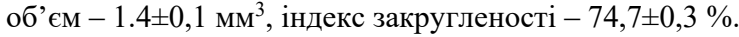

5. Насиджування яєць Jynx torquilla у середньому триває $13 \pm 0,2$ доби. На території НПП «Гомільшанські ліси» поблизу с. Гайдари пташенята вилупилися 14.05; в урочищі «Вакалівщина» 16.05, на території РЛП «Фельдман Екопарк» у 2019 році пташенята вилупилися 26.05 , у 2020 - 01.06. З'ясовано, що успішно $(\mathrm{n}=30)$ пташенята покинули гнізда. Успіх вилуплення становить $96,9 \%$, успіх розмноження - 91,0\%.

6. Завдяки пластичності у виборі місць для гніздування Jynx torquilla обирає ШГ, які $є$ повноцінно безпечним укриттям для виводку, захистом від хижаків та несприятливих погодних умов. Разом із тим заходи щодо розвішування ШГ в різних умовах дають змогу дослідникам полегшувати роботу при встановленні фенологічних спостережень за птахами, вивчати особливості їх репродуктивного періоду.

\section{References}

Andryushenko, Yu. A., Dyadicheva, E. A., \& Popenko, V. M. (2015). K kharakteristike vesennego naseleniya ptic suhostepnoj podzony Ukrainy $\mathrm{v}$ predelah mezhdurechya Dnepra i Molochnoj [To the Characteristics of the Spring Bird Population of the Dry Steppe Subzone of Ukraine within the Interfluve of the Dnieper and Molochnaya]. Berkut, 24(2), 83 (in Russian).

Assandri, G., Bernardi, A., Schmoliner, A., Bogliani, G., Pedrini, P., \& Brambilla, M. (2018). A matter of pipes: Wryneck Jynx torquilla habitat selection and breeding performance in an intensive agroecosystem. Journal of Ornithology, 159, 103-114.

Becker, D., \& Tolkmitt, D. (2011). Monitoring des Wendehalses Jynx torquilla in Sachsen-Anhalt. Ornithol. Jber. Mus. Heineanum, 29, 63-70.

Berndt, R. K. (2018). Zum Brutvorkommen des Wendehalses Jynx torquilla in Schleswig-Holstein. Corax, 23, 463-472.

Beskaravajnyj, M. M. (2012). Pticy Krymskogo poluostrova [Birds of the Crimean Peninsula]. Simferopol: BiznesInform, 203 (in Ukrainian).

Biletska, M. H., Solohor, K. A., \& Dobrovolska, N. A. (2009). Ptakhy lisovykh biotsenoziv Shatskoho natsionalnoho pryrodnoho parku [Birds of forest biocenoses of Shatsk National Nature Park]. Naukovyi visnyk Volynskoho natsionalnoho universytetu imeni Lesi Ukrainky. Ser.: Biolohichni nauky, 2, 200-204 (in Ukrainian).

Brünner, K., \& Rödl, T. (2018). Erfolgreiche Bestandsstützung beim Wendehals Jynx torquilla in den ostmittelfränkischen Sanden. Ornithol. Anz., 57, 45-51.

Butev, V. T., Zubkov, N. I., Ivanchev, V. P., Koblik, E. A., Kovshar, A. F., Kotyukov, Yu. V., Lyuleeva, D. S., Nazarov, Yu. N., Nechaev, V. A., Priklonskij, S. G., Pukinskij, Yu. B., Rustamova, A. K., Sorokin, A. G., \& Fridman, V. S. (2005). Sovoobraznye, Kozodoeobraznye, Strizheobraznye, Raksheobraznye, Udodoobraznye, Dyatloobraznye. Pticy Rossii i sopredelnyh regionov [Owls, Nightjars, Swifts, Rakshas, Hoopoes, Woodpeckers. Birds of Russia and adjacent regions]. Moskva. Tvorchestvo nauchnyh izdanij KMK, 285-297 (in Russian).

Chaplygina, A. B., Shupova, T. V., \& Nadtochij, A. S. (2016). Ornitofauna nacionalnogo prirodnogo parka «Gomolshanskie lesa» [Ornithofauna of the National Nature Park "Gomolshanskie Forests"]. Visnyk Dnipropetrovskoho universytetu. Seriia: Biolohiia. Ekolohiia: nauk. zhurn. Dnipropetr. nats. un-t im. 
O. Honchara. Dnipropetrovsk: Vyd-vo DNU im. O. Honchara, 24 (1), 124-133 (in Russian).

Chaplyhina, A. B. (2018). Dendrofilni horobtsepodibni (Rasseriformes) yak strukturno-funktsionalnyi element antropohenno transformovanykh lisovykh bioheotsenoziv Pivnichno-Skhidnoi Ukrainy [Dendrophilous sparrows (Rasseriformes) as a structural and functional element of anthropogenically transformed forest biogeocenoses of North-Eastern Ukraine]. Avtoreferat dysertatsii na zdobuttia naukovoho stupenia doktora biol. nauk 03.00.16. Dnipro, 40 p. (in Ukrainian).

Canady, A., \& Mošansky, L. (2017). Public Cemetery as a biodiversity hotspot for birds and mammals in the urban environment of Kosice city (Slovakia). Acta Zoologica Lituanica, 27(3), 185-195.

Del, Val E., Dreiser, C., Finkbeiner, W., \& Förschler, M. (2018). The Wryneck Jynx torquilla: a review of its breeding status and population trend on storm-deforested sites in the Northern Black Forest, 56, 9-13.

Dolenec, Z. (2020). Contribution to the oology of the Eurasian wryneck Jynx torquilla. Nat. Croat, 29 (1), 123-128.

Fesenko, H. V., \& Bokotei, A. A. (2002). Ptakhy fauny Ukrainy [Birds of the fauna of Ukraine]. Kyiv, 416 (in Ukrainian).

Gavrilov, A. E., Abaev, A. Zh., Zaripova, S. H., \& Lopatin, O. E. (2017). O gnezdovanii vertishejki Jynx torquilla v Dzhungarskom Alatau [About the nesting of the Jynx torquilla in the Dzhungarskiy Alatau]. Russkij ornitologicheskij zhurnal, 26, 1464, 2678-2679 (in Russian).

Gedeon, K., Grüneberg, C., Mitschke, A., Sudfeldt, C., Eikhorst, W., Fischer, S., Flade, M., Frick, S., Geiersberger, I., Koop, B., Kramer, M., Krüger, T., Roth, N., Ryslavy, T., Stübing, S., Sudmann, S. R., Steffens, R., Vökler, F., \& Witt, K. (2014). Atlas Deutscher Brutvogelarten. Atlas of German Breeding Birds. Stiftung Vogelmonitoring Deutschland und Dachverband Deutscher Avifaunisten, Münster.

Havryliuk, M. N., Iliukha, O. V., \& Borysenko, M. M. (2014). Stroky sezonnykh mihratsii ptakhiv u raioni Kremenchutskoho vodoskhovyshcha u 2003-2012 rr [Dates of seasonal migrations of birds in the area of the Kremenchug reservoir in 2003-2012]. Avifauna Ukrainy, 5, 71 (in Ukrainian).

Hoyt, D. F. (1979). Practical methods of estimating volume and fresh weight of bird eggs. Auk, 96(1), 73-77.

Knysh, M. P. (1998). Ptakhy okolyts biolohichnoho statsionaru «Vakalivshchyna» (anotovanyi spysok) [Birds in the vicinity of the biological station "Vakalovschina" (annotated list)]. Vakalivshchyna: do 30-richchia biostatsionaru Sumskoho pedinstytutu. Sumy, 99-120 (in Ukrainian).

Lystopadskyi, M. A. (2014). Zvolozhennia, yak faktor strukturnoi orhanizatsii naselennia ptakhiv derevnykh nasadzhen Biosfernoho zapovidnyka Askaniia-Nova [Humidification as a factor in the structural organization of the bird population of tree plantations of the Askania-Nova biosphere reserve]. Biolohichnyi Visnyk Melitopolskoho derzhavnoho pedahohichnoho universytetu imeni Bohdana Khmelnytskoho, 1, 73-100 (in Ukrainian).

Makatsch, W. (1976). Die Eider der Vogel Europas Leipzig, 2, $1-460$.

Matvienko, M. E. (2009). Ocherki rasprostraneniya i ekologii ptic Sumskoj oblasti (60-e gody XX st.) [Essays on the distribution and ecology of birds in the Sumy region (60s of the XX century)]. Sumi: Universitetskaya kniga, 210 (in Russian).

Merzlikin, I. R. (2021). Gnezdovanie vertishejki Jynx torquilla $\mathrm{v}$ metallicheskoj trube [Jynx torquilla beater nesting in a metal pipe]. Russkij ornitologicheskij zhurnal. 30, 2061, 1927-1928 (in Russian).
Myand, R. (1988). Vnutripopulyacionnaya izmenchivost ptichih yaic [Intrapopulation variability of avian eggs]. Tallin: Valgus, 195 (in Russian).

Nadtochij, A. S., \& Chaplygina, A. B. (2010). Dolgovremennye izmeneniya srokov prileta ptic $\mathrm{v}$ Harkovskuyu oblast [Long-term changes in the timing of the arrival of birds in the Kharkiv region]. Branta: Sbornik nauchnyh trudov Azovo-Chernomorskoj ornitologicheskoj stancii, 13, 50-62 (in Russian).

Nehoroshev, O. G., \& Kuranov, B. D. (2015). Gnezdovaya biologiya vertishejki Jynx torquilla $\mathrm{v}$ raznyh ekologicheskih usloviyah yuga Zapadnoj Sibiri [Nesting biology of the Jynx torquilla washer in different ecological conditions in the south of Western Siberia]. Russkij ornitologicheskij zhurnal, 24, 1138, 1559-1561 (in Russian).

Nikiforov, M. E., Yaminskij, B. V., \& Shklyarov, L. P. (1989). Pticy Belorussii : spravochnik-opredelitel gnezd i yaic [Birds of Belarus: a guide-guide for nests and eggs]. Minsk, Vyshejshaya shkola, 254-255 (in Russian).

Numerov, A. D., Priklonskij, S. G., Ivanchev, V. P., Kotyukov, Yu. V., Kashenceva, T. A., Markin Yu. M., \& Postelnyh A. V. (1995). Kladki i razmery yaic ptic yugo-vostoka Meshyorskoj nizmennosti [Clutches and egg sizes of birds in the southeast of the Meshchera lowland]. Tr. Okskogo zap., 18, 168 (in Russian).

Petrovych, O. Z. (2014). Ptakhy polezakhysnykh lisosmuh v mezhakh vozneseskoho raionu Mykolaivskoi oblasti u hnizdovyi period [Birds of sheltering forest belts within the Vozneseye region of the Nikolaev region during the nesting period]. News Biosphere Reserve "Askania Nova", 16,51 (in Ukrainian).

Pisotska, V. V., \& Yarys, O. O. (2021). Analiz vydovoho skladu ta chyselnosti ornitofauny lisosmuh vzdovzh avtoshliakhiv Kharkivskoi oblasti [Analysis of the species composition and number of avifauna of forest belts along the highways of the Kharkiv region]. Colloquium-journal, 1,18(105), 3-9.

Prokudin Yu. N., Dobrochaeva D. N., Zaverukha B. V., \& Chopyk V. Y. (1987). Opredelitel vysshih rastenij Ukrainy [Keys to higher plants of Ukraine]. Kiev: Naukova dumka, 1987, 548 (in Russian).

Reznichenko, S. M. (2013). Materialy k ornitofaune Karkaralinskogo nacionalnogo parka [Materials for the avifauna of the Karkarali National Park]. Ornitol. vestn. Kazahstana i Srednej Azii, 2, 177-185 (in Russian).

Rudenko, A. G., Chaplygina, A. B., Nadtochij, A. S., Rudenko, V. P., Litvinenko, S. P., \& Evtushenko, G. A. (2016). Rezultaty inventarizacii migriruyushih ptic na ostrove Dzharylgach v avguste 2015 goda [Results of the inventory of migratory birds on Dzharylgach Island in August 2015]. Branta: Sbornik nauchnyh trudov AzovoChernomorskoj ornitologicheskoj stancii, 19, 99-111 (in Russian).

Shevtsov, A. O. (2008). Fenolohiia vesnianoi mihratsii ptakhiv v Oleksandriiskomu raioni Kirovohradskoi oblasti [Phenology of spring migration of birds in the Alexandria district of Kirovograd region]. Avifauna Ukrainy, 4, 97 (in Ukrainian).

Shumaev, V. S. (2021). Lesnoj konyok Anthus trivialis i vertishejka Jynx torquilla, razbivshiesya vo vremya migracii o provoda vysokovoltnoj LEP v doline reki Chergi (Gornyj Altaj) [Forest pipit Anthus trivialis and jynx torquilla collapsed during migration on the wires of a highvoltage transmission line in the valley of the Cherga river (Gorny Altai)]. Russkij ornitologicheskij zhurnal, 30, 2074, 2510-2512 (in Russian).

Shupova, T. V., \& Chaplygina, A. B. (2016). Ornitofauna zakaznika obshegosudarstvennogo znacheniya Luchkovskij [The avifauna of the national reserve Luchkovsky]. Visnyk Kharkivskoho natsionalnoho universytetu imeni V. N. Karazina. Seriia: Biolohiia, 26, 148-156 (in Russian). 
Somov, N. N. (1897). Ornitologicheskaya fauna Harkovskoj gubernii [Ornithological fauna of the Kharkov province]. Kharkov, Tip. A. Darre, 273-276 (in Russian).

Tarusova, N. V., Aiubova, E. M., Kinash, Ye. M., \& Mitin, M. S. (2019). Vplyv vikovoi struktury lisosmuh PivnichnoZakhidnoho Pryazovia na formuvannia hnizdovoi ornitofauny [Influence of the age structure of forest belts in the North-Western Azov region on the formation of nesting avifauna]. Topical issues of methods of teaching natural: International scientific and pract. conf. (Lublin, 27-28. 12 2019), 99-104 (in Ukrainian).

Taylor, L. T., Hadžalic, S., Horvat, K., \& Lelas, L. (2020). The breeding birds of Palud, Istria. Larus, 55, 34-41. 